\title{
Scenes of Goddess Amaunet in the temple of Medinet Habu
}

Aya Ahmed El-Mahdy - Khaled El Bassiouny - Mofida EL weshahy

Tourist Guidance department Touristic - Faculty of Tourism and Hotels - Suez Canal University

\begin{abstract}
The temple of (Medinet Habu) had no identical meaning for the word Habu, it may had been derived from the name of Amunhotep II the son of Habu, who was minister, medical scientist, built the palace of amonhotepIII, and he had been adored in Greco-roman period.the temple of medinet-Habu is situated on the western bank of the river Nile in Luxor, and it is considered not only one of the most important temples in Luxor, but also all over Egypt, it consists of several small shrines and halls, it had representations for all the most important gods and goddesses in Ancient Egypt, and also it was a central place for adoring the Ogdoad of Hermopolis, particularly goddess Amaunet , as a main member in the Ogdoad and also a counterpart for the great god Amun, and she had several priests in the temple.
\end{abstract}

Research aims to: Study the scenes and the most important Representations of goddess Amaunet in the temple of Medinet Habu; Illuminate the major role she played in the temple and her relation with the other deities .

Key words: (Amaunet- Habu- Ogdoad)

\section{Introduction:}

Medinet Habu ${ }^{(1)}$, the modern name of the southernmost area of the Theban necropolis ${ }^{(2)}$. Its name may has been taken from the name of the temple of Amenophis the son of Hapu ${ }^{(3)}$. In the beginning of the 21st Dynasty. it was known as iAt - TAmt ${ }^{(4)}$, later DAmt ${ }^{(5)}$. It is a temple complex consisting of the main temple of Ramses III and several smaller structures from different periods ${ }^{(6)}$. The main temple of Ramses III is well preserved decorated and designed ${ }^{(7)}$, providing an impressive example for the temples in the new kingdom ${ }^{(8)}$. It was a sacred place where the

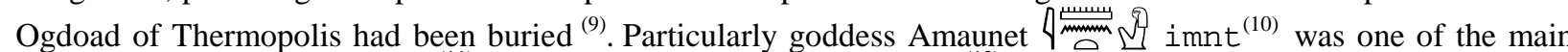
female members in the Ogdoad ${ }^{(11)}$. She was Amun's primeval consort ${ }^{(12)}$, her name is meaning " the female hidden one"(13) the pair represented "hiddenness"(14). Amaunet was self created ${ }^{(15)}$. She was depicted as a woman wearing the red crown of lower Egypt. ${ }^{(16)}$ Sometimes she was identified with goddess Neith ${ }^{(17)}$ as a compound goddess ${ }^{(18)}$. There were many priests serving the cult of goddess Amaunet ${ }^{(19)}$. She was rarely mentioned in ancient Egyptian texts ${ }^{(20)}$.She was often represented as a woman, ${ }^{(21)}$ wearing a long tight robe. ${ }^{(22)}$. Amaunet also referred to the northern wind ${ }^{(23)}$, her shadow among the primeval gods was a symbol for protection ${ }^{(24)}$. Amaunet moved with Amun to the temple of karnak since the reign of king Senwesert I in the Middle Kingdom ${ }^{(25)}$, played however a less prolific role than Amun's other wife Mwt. ${ }^{(2)}$

\section{Scenes of goddess Amaunet in the temple of Medinet Habu:}

\section{Doc.1: A scarab bears the name}

-Description: goddess Amaunet was deeply graved behind the background of a scarab which is surrounded by the infinite serpent of the universe

-Type of design: simple name.

- Location: southeast corner of the precinct in the area of the second fellahin village ${ }^{(4)}$.

- Comment: it appears older than the stratum because its design is known from the eighteens dynasty foundation deposits of Hatshepsut at Deir El bahari ${ }^{(5)}$.

Doc. 2: The temple of the eighteenth dynasty, back of the gateway in the Ptolemaic pylon.

The scene is represented on the left half of the gateway, the king Ptolemy X Soter II making offerings before two pairs (four elements of the ogdoad of Hermopolis) are sitting on their thrones in human forms. Female members are represented wearing long wig on their head, holding $\mathrm{WAD}^{(6)}$ scepter in the right hand and anx ${ }^{(7)}$ symbol in the left one. Male members with false beards hold wAs ${ }^{(8)}$ scepter in the right hand and anx symbols in the left one. fig.2 $(\mathbf{a}, \mathbf{b}, \mathbf{c})^{(9)}$.

Doc. 3: The temple of the eighteenth dynasty, the Ptolemaic pylon, third register ${ }^{(10)}$.

- King Ptolemy X Soter presents bread and water offerings to god Amun and his counterpart goddess Amaunet.

Text of goddess Amaunet reads:

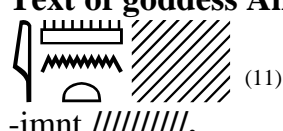

-imnt I/IIIIIII/.

Doc.no4: The temple proper, second court, portico, north end, upper register above doorway.

-The scene represents king Ramses III offering lettuce with both hands to goddess Amaunet in a human body wearing the red crown of Lower Egypt and a long tight robe making ritual of greeting nini ${ }^{(12)}$ with her arms to king Ramses the third, a lotus ${ }^{(13)}$ flower was placed in front of her, and the following god imn- Ra KA mwt.f (14), wearing the red crown with two long green feathers ${ }^{(15)}$ on it, raising the flagellum $n \times x^{(16)}$ in the right hand. (fig.3) ${ }^{(17)}$

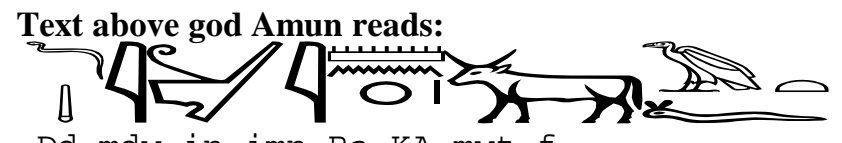

- Dd mdw in imn-Ra KA mwt.f.

-Words said by god Amun- Re- ${ }^{18}$ Kamutef. 
Text behind god Amun reads:

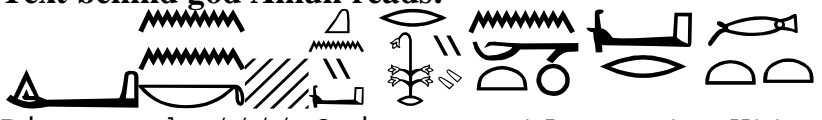

Di $n \mathrm{n} . \mathrm{k} / / / /$ Qni r rsy tAwy nxt mHtt

-Given victory to you//// strong man of the southern and the northern lands.

Text above goddess Amaunet reads : ${ }^{(19)}$

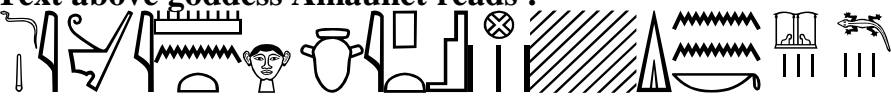

Dd mdw in imnt $\mathrm{Hr}$ ib ipt swt //// di.n n.k sdw aSA

Words said by goddess Amaunet who resides in the temple of Karnak ////, given to her many festivals.

Text behind goddess Amaunet reads:

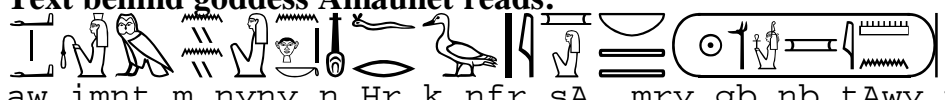

aw imnt m nyny $n$ Hr.k nfr sA. mry gb nb tAwy wsr mAat Ra mry imn

Arms of goddess Amaunet are greeting you the beautiful son, beloved of god geb, master of the two lands the pharaoh Ramses the third son of god Re.

Doc. 5: The temple Proper, second court, column43, north.

Scene represents pharaoh Ramses the third, standing in front of A lotus flower offering ointment with his two hands to goddess Amaunet who stands wearing the red crown of Lower Egypt on her head, a long tight robe holding wAD scepter in the right hand and anx symbol in the left one. fig.4 $\left(\mathbf{a}^{(20)}, \mathbf{b}^{(21)}, \mathbf{c}\right)$.

Text above goddess Amaunet reads:

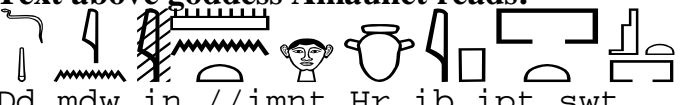

d maw in $/$ imnt

Words said by goddess Amaunet,who resides in karnak temple.

Text behind goddess Amaunet reads:

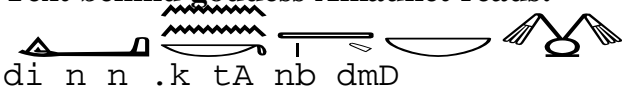

Given to you, lord of the united land.

Doc. 6: The temple proper, Treasury, Northeast Room, south wall

Goddess Amaunet, as a human body, wears the red crown of lower Egypt on her head, long tight robe without sleeves, a well designed collar, holds anx the symbol of life in the right hand and wAD scepter in the left one, many plants and lotus flowers are represented on a table in front of her, she is following god Amun $-\mathrm{Re}-\mathrm{ka}-\mathrm{mwt}-\mathrm{f}$ , who wears the red crown with its two long green plumes, raising $n \times x$ with the right hand and wears a collar around his neck and a lotus flower is represented in front of him the scene is represented in a well decorated shrine . (fig.5) ${ }^{(22)}$

Text above goddess Amaunet reads : ${ }^{(23)}$

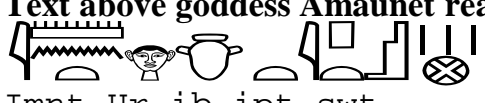

Imnt $\mathrm{Hr}$ ib ipt swt

Amaunet ,who resides in the temple of karnak.

Text behind goddess Amaunet reads:

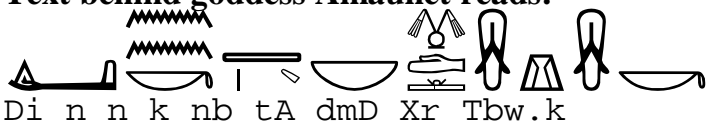

Given to you all the united lands under your sandals.

Text behind god Amun reads:

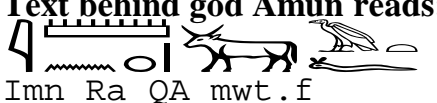

Amun RE- the bull of his mother.

Doc. 7: the temple proper, treasury, southeast Room (11), south wall

Goddess Amaunet stands behind god Amun in the shrine, wears the red crown of lower Egypt on her head, well designed necklace on the chest and a long tight robe, she is adoring god with her right hand and touching his shoulder by the left one, god Amun sits on the throne, holds the symbol of life anH in the right hand and wAs scepter symbolizing power in the left one and smells a lotus flower. (fig. 6) ${ }^{(24)}$

Text above goddess Amaunet reads:

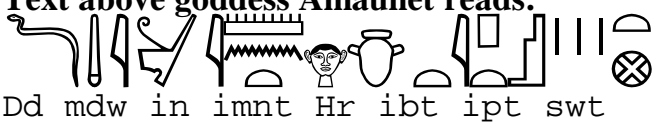

Words said by goddess Amaunet in the centre of the temple of Karnak.

Text behind goddess Amaunet reads:

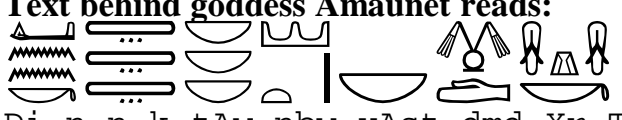

Di $n \mathrm{n} k$ tAw nbw xAst dmd Xr Tbw.k

-Given to you all the lands and the desert together under your sandals.

Text behind god Amun reads: 


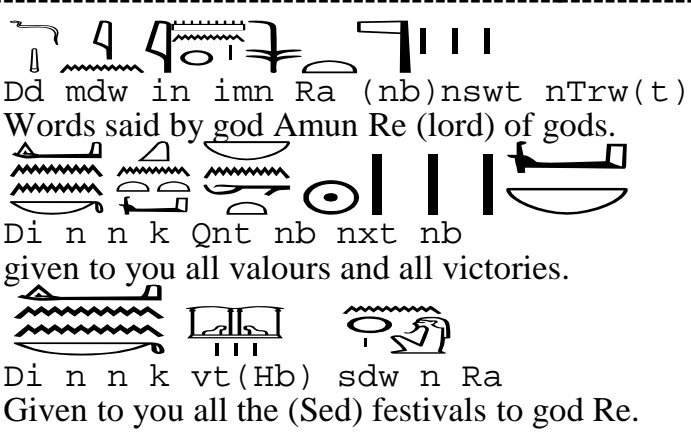

Doc. 8: The temple proper, second court, south colonnade, shaft of column 38

Scene represents goddess Amaunet as a female standing and wearing the red crown of lower Egypt and a long tight robe, holding WAD scepter in the right hand and the symbol of life anx in the left one, she is following god AmunRe- Ka-mwt-f who stands wearing the red crown with its two long plumes on the head and raises nxx symbol with the left one. (fig. 7) ${ }^{(25)}$

Text above goddess Amaunet reads : ${ }^{(26)}$

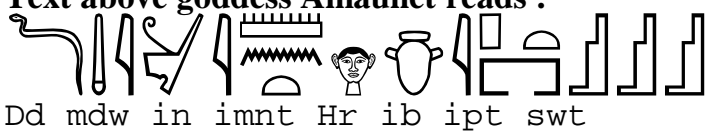

Words said by goddess Aumaunet in the centre of the temple of karnak.

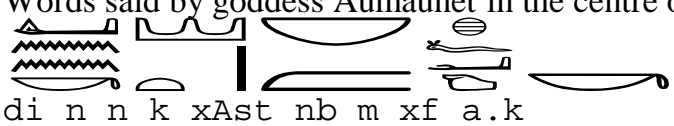

di $n \mathrm{n} k$ xAst $\mathrm{nb} m$ xf $a . k$

Given to you all your grasps (captures in the war) in the desert.

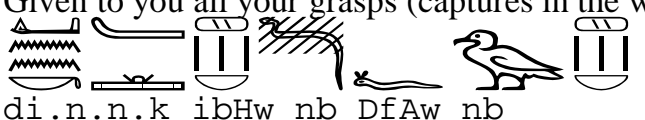

di.n.n.k ibHw nb DfAw nb

Given to you all teeth (and) all provisions.

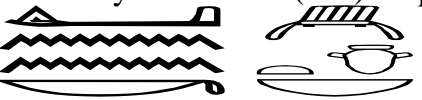

Di $n \mathrm{n} k$ Awt ib.k

Given to you all the joyfulness of heart.

Text behind goddess Amaunet reads:
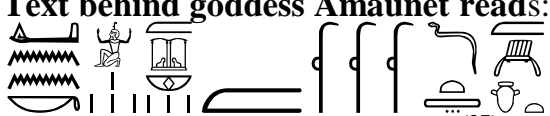

Di n.n k HHw m Hb- sd ${ }^{\prime 27)}$ m rnpw Dt $m$ nb Awt ib.k

Given to you millions of years of Sed festivals and all the joyfulness of heart forever.

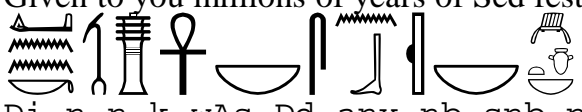

Di n n.k wAs Dd anx nb snb nb Awt ib.k

Given to you all the power, stability, life, health and all joyfulness of the heart to you.

Text above god Amun reads:

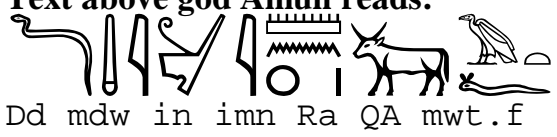

Words said by god Amun- Re the bull of his mother.

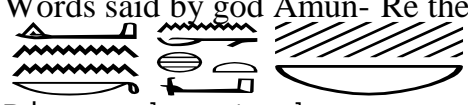

Di n.n k nxt nb

Given to you all the victories.

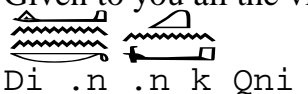

Given to you all the powerful.

Ti.n.n.k .Ati.k rext behind god Amun reads:

Given to you all your attacks to the desert lord of eternity.

Doc. 9: the temple proper, second court, west colonnade, shaft of column46.

Scene represents goddess Amaunet wears the red crown of lower Egypt, wears the long tight robe, holds the scepter of by the left hand and adoring the king Ramses the third by the right hand, the king Ramses the third wears the crown of $\operatorname{xprS}^{(28)}$ and presents offerings to various gods. (fig. 8) ${ }^{(29)}$. 
Text above goddess Amaunet reads:

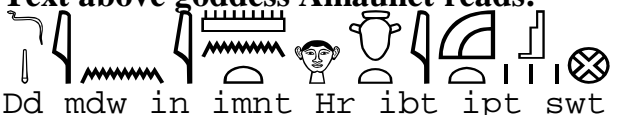

Words said by goddess Amaunet in the centre of the temple of karnak.

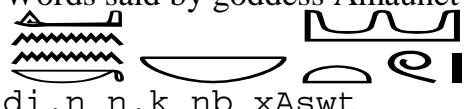

Given to you all the deserts.

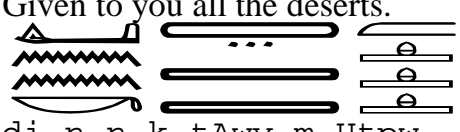

di.n.n.k tAwy m Htpw

givin to you the offerings of the two lands

Doc. 10: The temple proper, first pylon, north tower, top, interior, passage at foot of upper staircase, east wall The Scene represents goddess Amaunet wearing the red crown of lower Egypt and a long tight robe, holding a stick in the left hand and anx the symbol of life in the right one, plants and Lotus flower are placed in front of her, she is following god Amun-Re - Ka- mwt-f who raises $n \times x$ sign with the right hand and wears the red crown with its two long plumes on the head. (fig. 9) ${ }^{(30)}$

Text above goddess Amaunet reads:

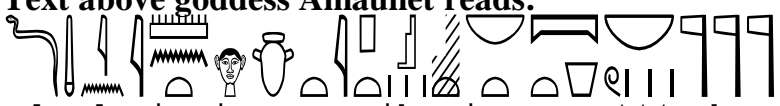

Dd mdw in imnt $\mathrm{Hr}$ ibt ipt swt/// nbt pt nbw nTrw

Words said by goddess Amaunet who resides in the temple of karnak, master of the sky, master of all gods.

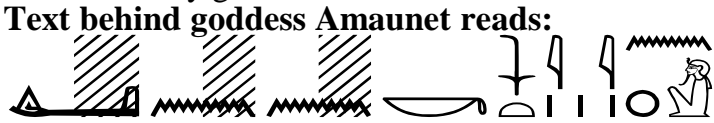

di.n.n.k nsyt.n.Ra

given to you the royality of god Re.

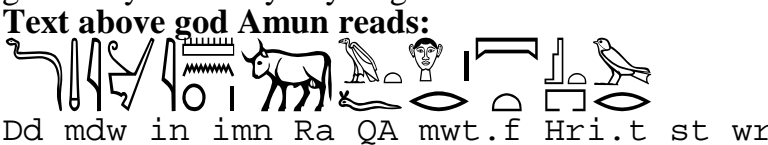

Words said by god Amun -Re- the bull of his mother concerning a great throne. Di/ n.n.k Qni nb nxt k

Given to you supremacy (and) all your victories.

Doc. 11: the temple proper, room40, east wall

The Scene represents goddess Amaunet, as a female human one, she stands in a shrine, wears the red crown of lower Egypt a long tight well designed robe with belt, a collar around the neck, bracelets in the left hand; she is adoring god Amun with her right hand and touching him with the left one. God Amun is represented standing in the shrine as a lion headed human body with a sun disk and a serpent in front of it; he wears a long wide robe with long wide sleeves. He holds HQA scepter in the right hand and nxx scepter in the left one and places them on his chest. (fig. 10) ${ }^{(31)}$.

Text behind god Amun reads:

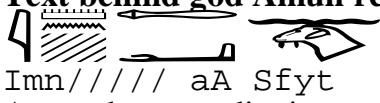

Amon the great dignity.

Text behind goddess Amaunet reads:

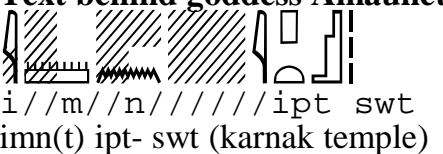

Doc. 12: The temple proper, room45, East wall

The Scene represents pharaoh Ramses the third in front of a lotus flower purifying the statue of king Re- Har-Akhte which is placed sitting on the throne in a , in a ram headed- human body form, holding sistrums on the chest and wearing a long tight robe with long wide sleeves in the presence of goddess Amaunet who wears long tight robe and the red crown of lower Egypt on the head with bangles around the leg; she is adoring god Amun with the right hand and placing her left one under his right arm. (fig. 11)

Text behind god Amun reads:

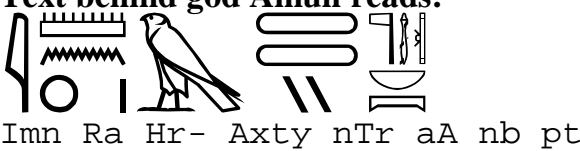

Amun Re- her- akhtey the great god lord of the sky.

Doc. 13: the temple proper, roof terraces, south wall, East end, (fig. 12) ${ }^{(33)}$ 
The Scene represents goddess Amaunet as a human female form wearing the red crown of Lower Egypt with her face destroyed, holding WAD scepter in the right hand; she is following god

$\mathrm{Khonsu}^{(34)}$ in ahuman falcon- headed form with a disk and crescent moon on the head ; the rest of his body is destroyed and he holds wAs scepter in his right hand.

Text above goddess Amaunet reads:

Pी

Dd mdw in imnt Hry (t) - ib ipt swt di.n.n.k sd nbw mi Ra

Words said by goddess Amaunet in the centre of the temple of karnak, given to you all the festivals like god RE.

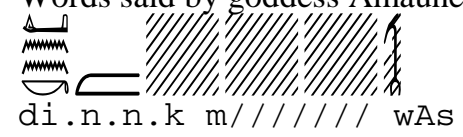

given to you in wAs ( $t$ ) Thebes

Text above god khonsu reads:

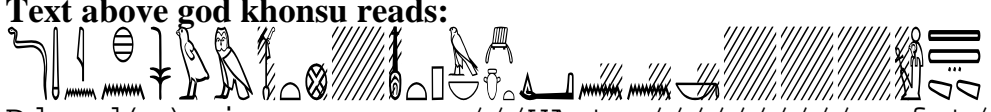

Dd mo(w) in xnsw m ///WAst $/ / / / / / / / / /$ nfrt/// p Hr nb Awt ibt di.n.n.k /////////tAwy

Words said by god khonsu in//I// thebes //I/// the beautiful/// the falcon Horus lord of the joyfulness of the heart, given to you ////////////he two lands.

Doc. 14: the temple proper, exterior south wall, west of second pylon, frieze above the temple calendar

Goddess Amaunet stands in a human female body wearing the red crown of Lower Egypt and a long tight robe, she is following god Amun - Re who sits on the throne, his form is destroyed, and he wears the crown of two long plumes on his head. (Fig. 13) ${ }^{(3)}$

Text above goddess Amaunet reads:

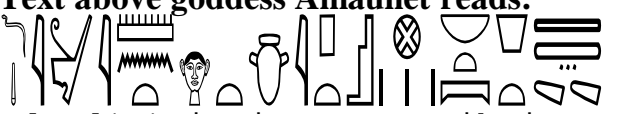

Dd mo(w) in imnt Hryt ib ipt swt nbt pt Hnt tAwy

Words spoken by goddess Amaunet who resides in the temple of karnak, lady of the sky mistress (of) the two lands.

Text behind goddess Amaunet reads:

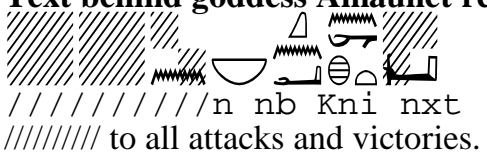

Text behind god Amun reads:

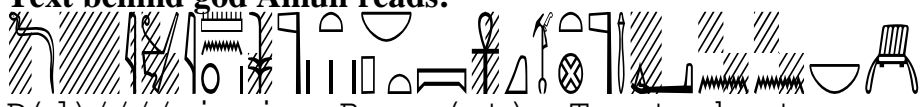

$\mathrm{D}(\mathrm{d}) / / / /$ in imn Ra ns (wt) nTrwrt nb pt anx wAst nTr aA di n.n nb Aw (t)

Words spoken by god Amun -Re lord of all gods, lord of the sky life, the great god (of) thebes, given to you all the joyful.

Doc. 15: the eastern high gate, north porter's lodge, west face

The Scene represents goddess Amaunet as a human female one standing and wearing the red crown of lower Egypt on the head and a long tight robe; she is adoring god Amun Re- Harakhty with the right hand; od is represented in a human body, his face is destroyed, he holds the sun disk and a serpent in front of it above his head, small part of the symbol of power wAs scepter in his left hand is apparent, following goddess, is the king Ramses the third who wears xprS crown on the head and holds HkA and nxx scepters, he placed them on his chest. (Fig. 14) ${ }^{(36)}$

Text above goddess Amaunet reads:

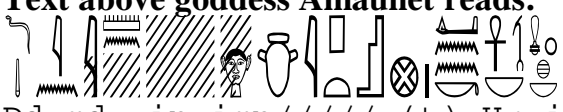

Dd mdw in imn///// (t) $\mathrm{Hr}$ ib ipt swt di.n.n.k nb anx wAs mi Ra $x(a)$ nb

Words spoken by goddess Amaunet, who resides in karnak, given to you all the life and dominion, like god Re every day.

Text above god Amun reads:

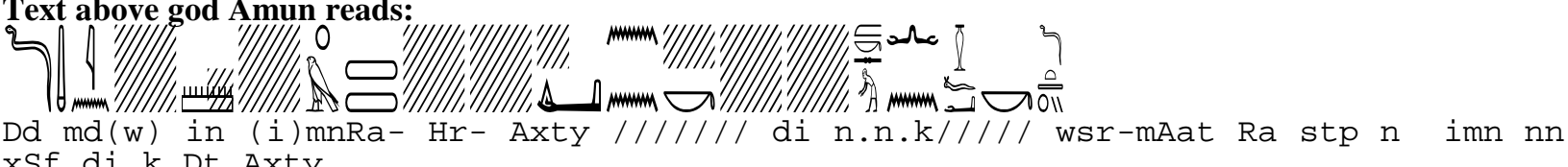

Dd ma(w) in (i)mnRa- Hr-Axty ////// di n.n.k//// wsr-mAat Ra stp $\mathrm{n}$ imn nn

Words spoken by Amun-Re,givn to you/// ////, (Usermare-Setepenamon), given to you a great reign like Re (every) day.

Doc. 16: Temple of Thutmose the third, northern face (Fig. 15) ${ }^{(37)}$

King Ramses the third offering sistra to goddess Amaunet, in human female form wearing the red crown of Lower Egypt and a long tight robe. 
Scenes of Goddess Amaunet in the temple of Medinet Habu

Aya Ahmed El-Mahdy - Khaled El Bassiouny - Mofida EL weshahy

Conclusion:

Based on the above documents, many elements could be realized from the texts and scenes concerning goddess Amaunet in the temple of Medinet Habu.

- $\quad$ The titles of goddess Amaunet.

- The relation of Amaunet with other gods.

- The different forms of goddess Amaunet.

- $\quad$ The rare scenes of Amaunet.

Goddess Amaunet took many titles which express her as an essential goddess in the temple of Medinet Habu; these titles accompanied her name on the wall scenes of the temple. The following table represents her titles accompanied with the figures.

\begin{tabular}{|l|l|c|}
\hline \multicolumn{1}{|c|}{ Titles } & \multicolumn{1}{|c|}{ Meaning } & Figure no. \\
\hline Hr ib ipt swt & Residing in the temple of karnak & $5,6,7,8,18$ \\
\hline Hr ibt ipt swt & Residing in karnak temple & $9,10,12$ \\
\hline Hr ibt ipt swt nbt pt nbw & $\begin{array}{l}\text { Residing in the temple of karnak, } \\
\text { lady of the sky, master of all the } \\
\text { gods }\end{array}$ & 13 \\
\hline Ipt swt ipt swt & The temple of karnak & 14 \\
\hline Hryt ib ipt not pt & Residing in karnak temple & $\begin{array}{l}\text { Residing in karnak temple, lady of } \\
\text { The sky, master of the two lands }\end{array}$ \\
\hline $\begin{array}{l}\text { Hryt ib ipt } \\
\text { tAwy }\end{array}$ & 17 \\
\hline
\end{tabular}

Table No.2: The relation of Amaunet with the other ogods:

The accompanied scenes of goddess Amaunet reflect her relation with other deities.

\begin{tabular}{|l|l|}
\hline The deities & Figure no. \\
\hline Amaunet with the ogdoad of thermopolis & $2,3,4$ \\
\hline Amaunet with Amun $-\mathrm{Ra}-\mathrm{QA}-\mathrm{mwt} . \mathrm{f}$ & $5,9,13$ \\
\hline Amaunet with Amun Ra & 10,17 \\
\hline Amaunet with Amun aA Sfty & 14 \\
\hline Amaunet with Amun Ra Axty & 15,18 \\
\hline Amaunet with khonsu & 16 \\
\hline
\end{tabular}

Table No.3:The different forms of goddess Amaunet:

\begin{tabular}{|l|l|}
\hline scene & Figure no. \\
\hline $\begin{array}{l}\text { Wears a long wig as a female } \\
\text { member of the ogdoad }\end{array}$ & 2 \\
\hline $\begin{array}{l}\text { Holds wAD scepter and anx } \\
\text { symbol }\end{array}$ & $2,6,7,8,9,11$ \\
\hline Holds only wAD scepter & 16 \\
\hline Holds scepter & 12 \\
\hline Wears the red crown & $5,6,7,8,9,10,11,12$ \\
& $13,14,15,16,17,18$, \\
\hline
\end{tabular}

Table No.4:The rare scenes of goddess Amaunet:

\begin{tabular}{|l|c|}
\hline scene & Figure.no. \\
\hline $\begin{array}{l}\text { Goddess Amaunet making is ritual of nini } \\
\text { greeting king Ramses the third }\end{array}$ & 5 \\
\hline
\end{tabular}


Journal Of Association of Arab Universities For Tourism and Hospitality Volume 15 - December 2018 -- (special issue) Page : ( 40- 51 )

\section{Figures:}

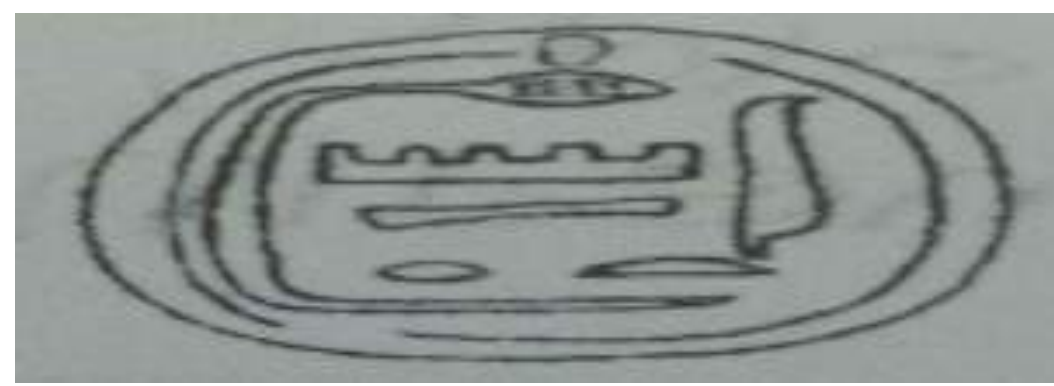

Fig.1- A scarab bears the name 40

- Southeast corner of the precinct in the area of the second fellahin village.

- Teeter, Emily, OIP118, Scarabs, scaraboids, seals, and seal impressions from Medinet Habu, Chicago, 2003 , p.19.

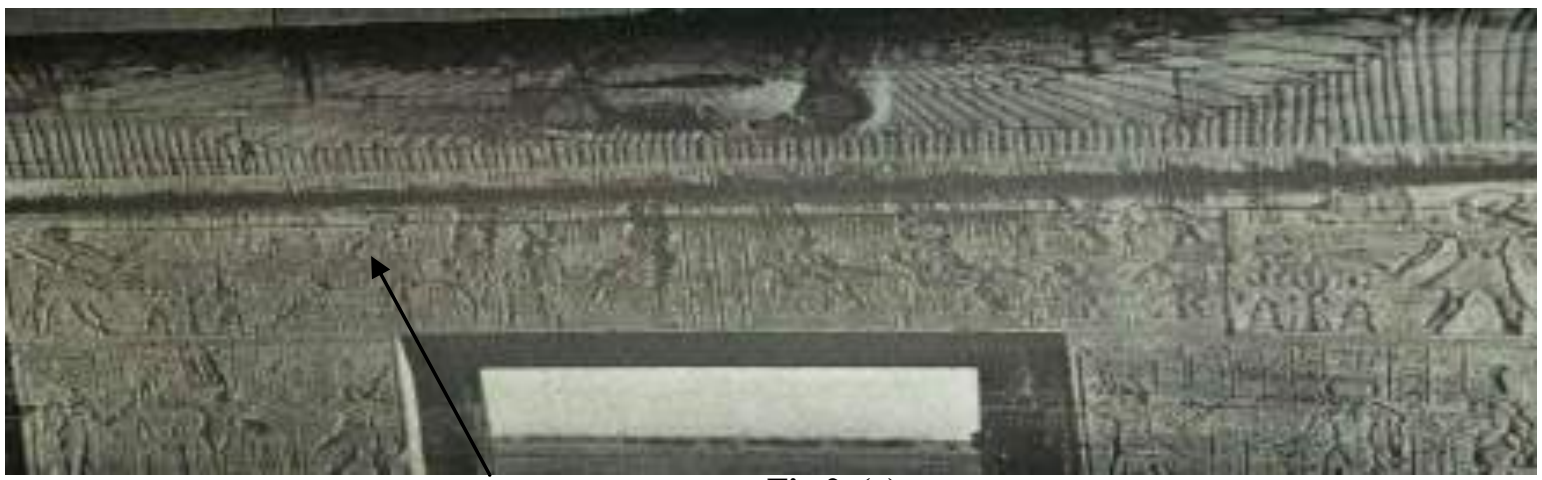

Fig.2, (a)

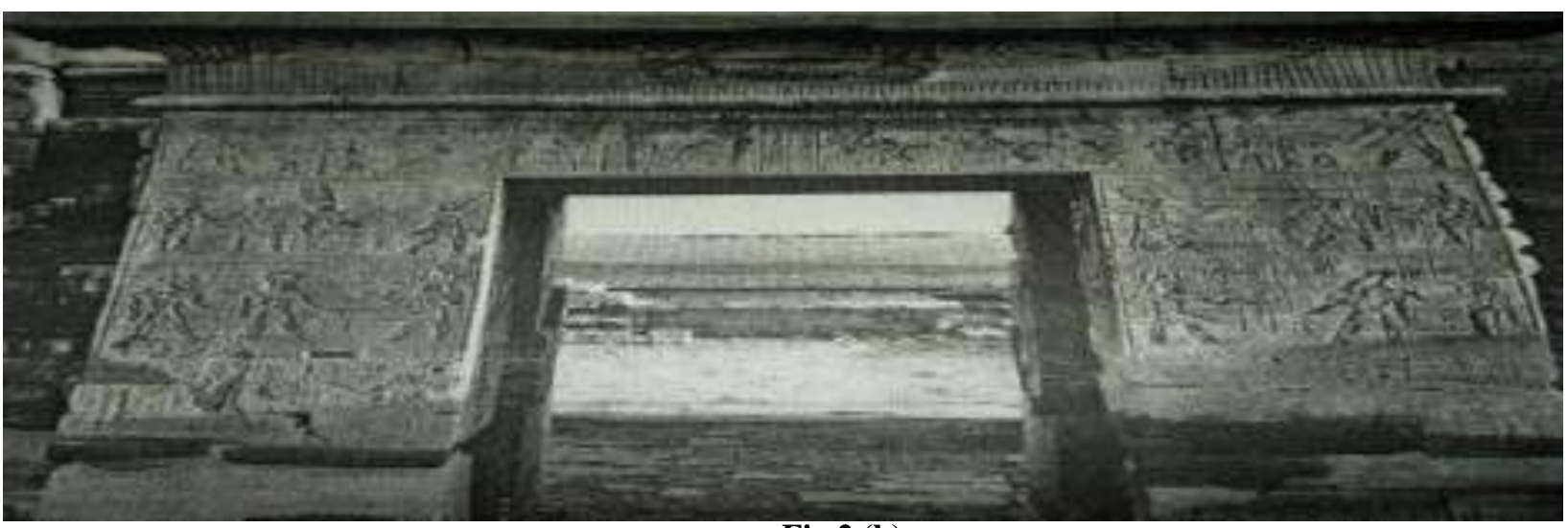

Fig.2,(b)

- Back of the gateway in the Ptolemaic pylon

Holscher.U.. OIP 41.The Excavation of Medinet Habu. Vol.2.Chicago,1939. P1.38, 39

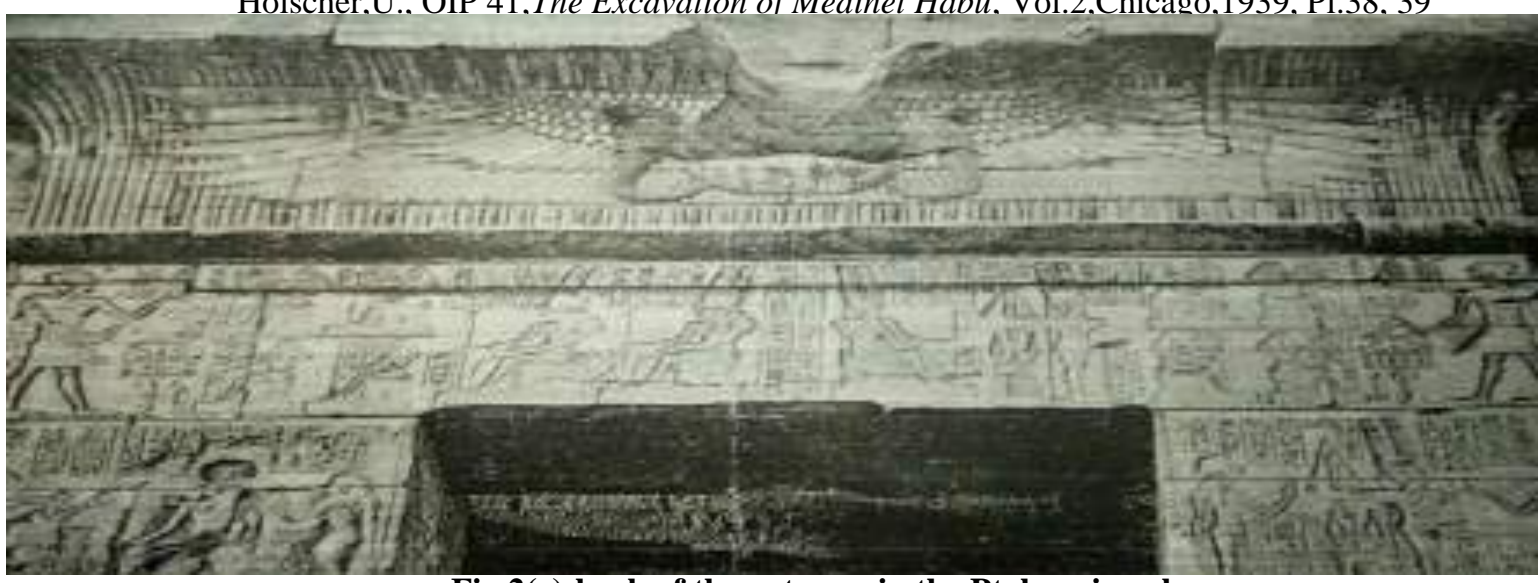

Fig.2(c)-back of the gateway in the Ptolemaic pylon.

- Jequier, Justave, L’ Architecture III, Les Temples Ptolemaiques et Romains, Paris, 1924, Pl. 10. 
Scenes of Goddess Amaunet in the temple of Medinet Habu

Aya Ahmed El-Mahdy - Khaled El Bassiouny - Mofida EL weshahy

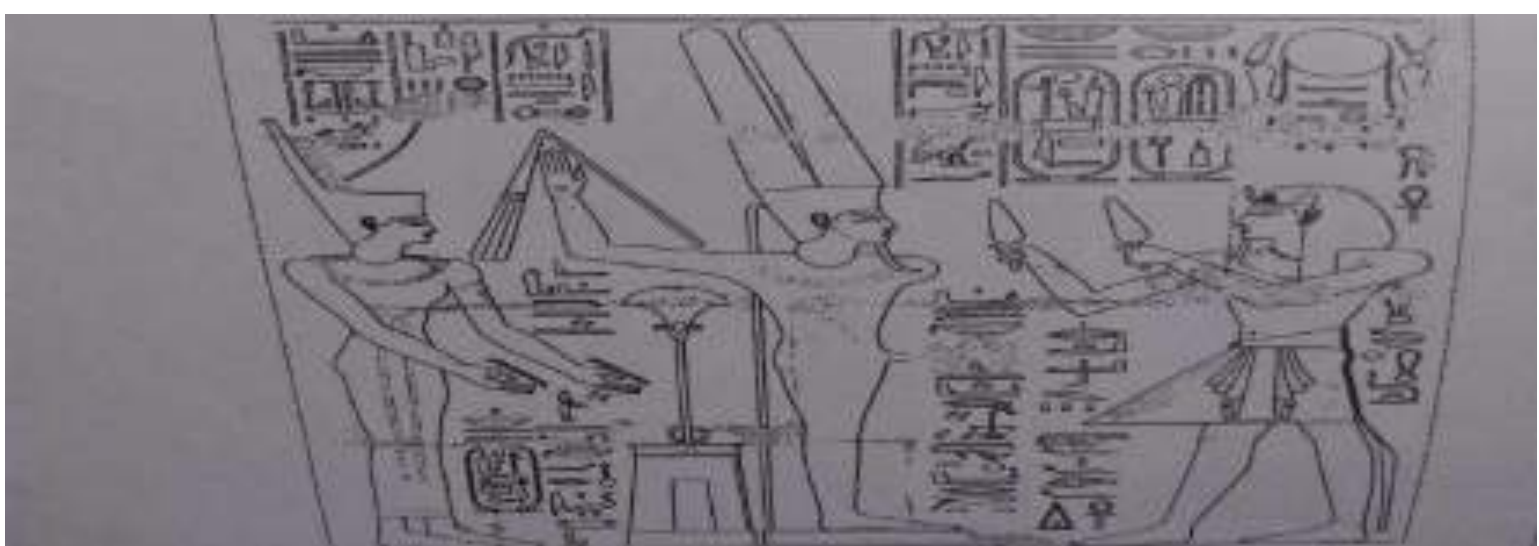

Fig.3- The temple proper, second court, portico, north end, upper register above doorway. -The Epigraphic Survey, OIP83, Medinet Habu, Vol.5, Chicago, 1957, pl. 284(A).

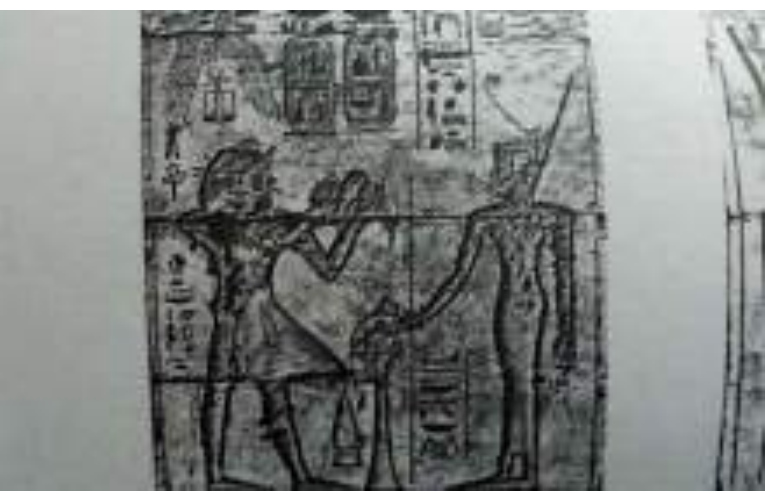

Fig.4, (a)

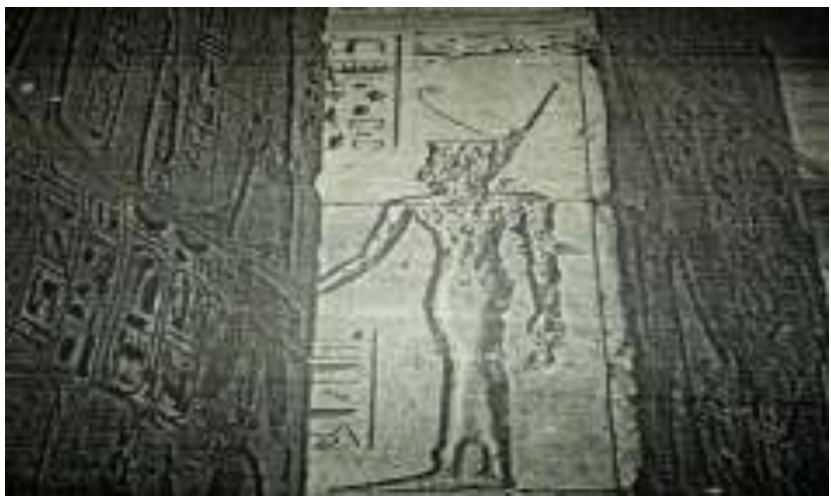

Fig.4, (b)

- The temple Proper, second court, column43, north. - The Epigraphic Survey, OIP83, Medinet Habu, Jéquier, G., L’Architecture et la Décoration Dans Vol.5, Chicago, 1957, pl. 274(A). l'ancienne égypte, II, Paris, 1922, P1.59/2.

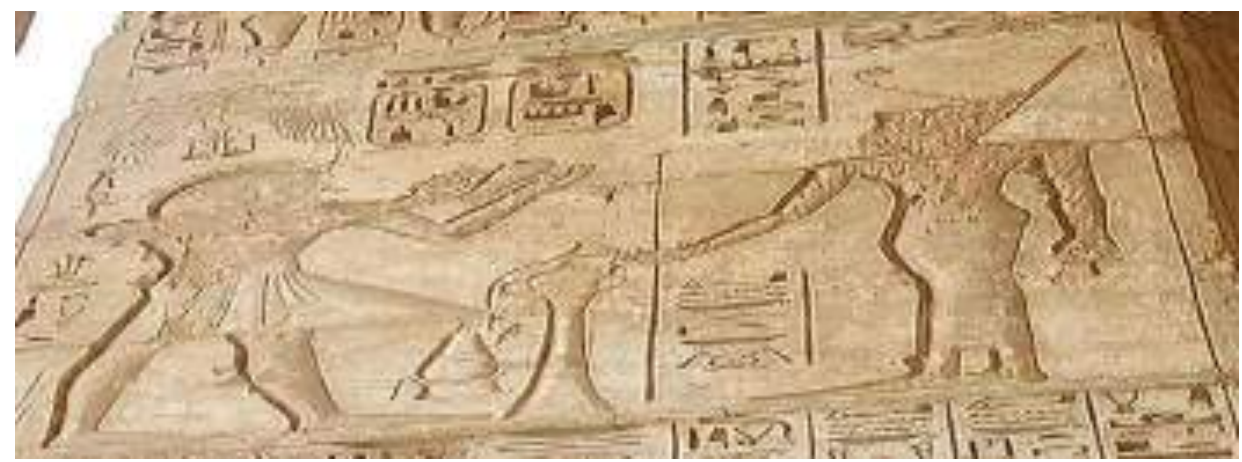

Fig.4, (c)- The temple Proper, second court, column43, north. -by the researcher

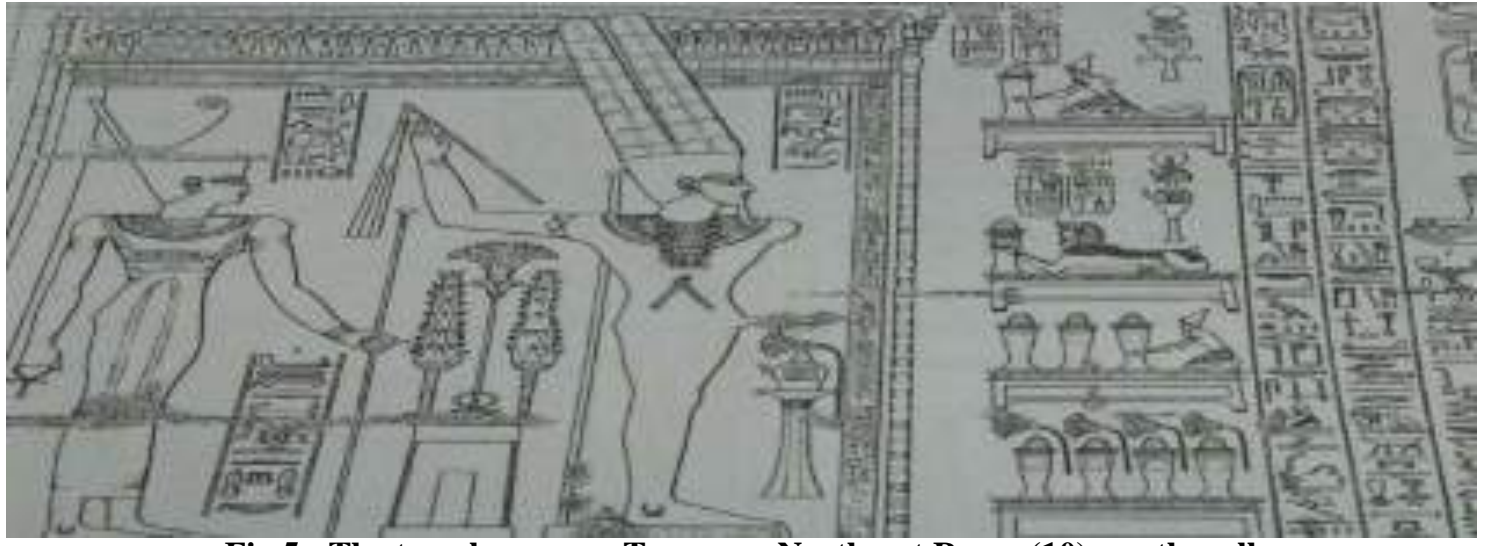

Fig.5 - The temple proper, Treasury, Northeast Room (10), south wall

-The Epigraphic Survey, OIP83, Medinet Habu, Vol.5, Chicago, 1957, pl324. 


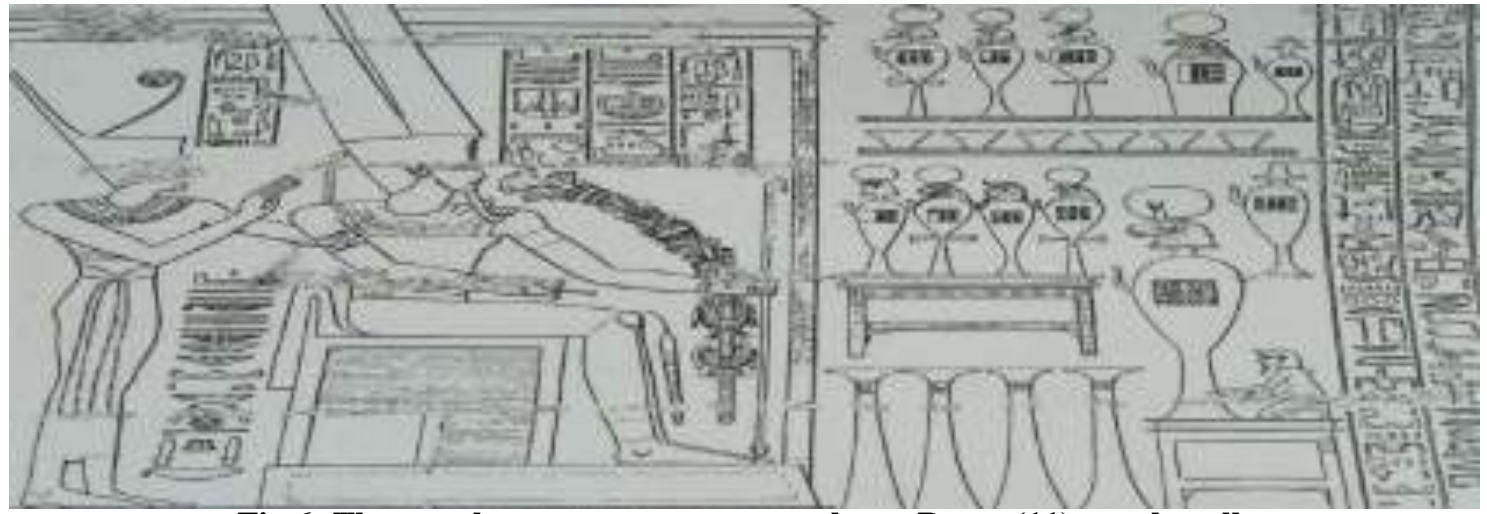

Fig.6- The temple proper, treasury, southeast Room (11), south wall.

-The Epigraphic Survey, OIP83, Medinet Habu, Vol.5, Chicago, 1957, pl.327.

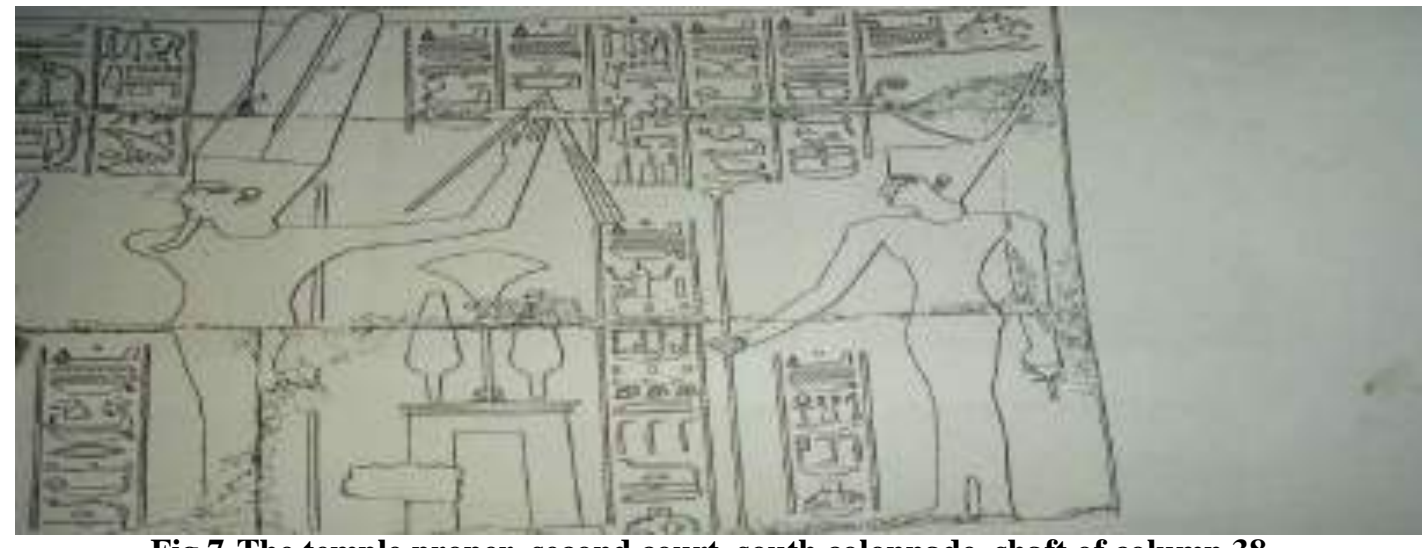

Fig.7-The temple proper, second court, south colonnade, shaft of column 38 .

The Epigraphic Survey, OIP84, Medinet Habu, Vol. 6, Chicago, 1963, pl.366.

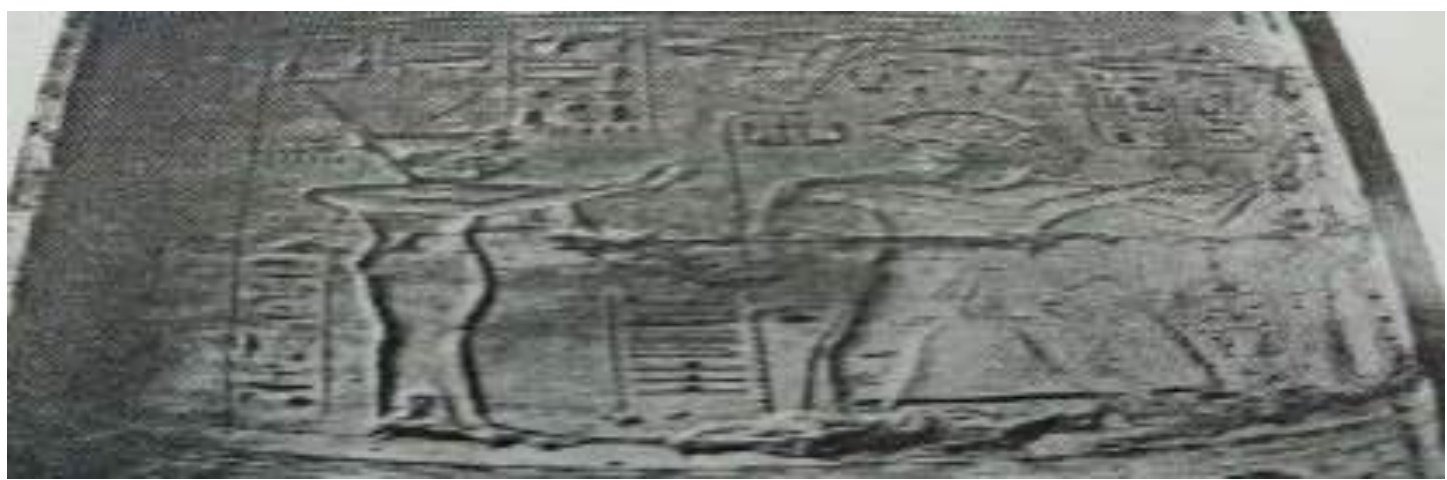

Fig.8 - The temple proper, second court, west colonnade, shaft of column46

- The Epigraphic Survey, OIP84, Medinet Habu, Vol. 6, Chicago, 1963, pl.374.

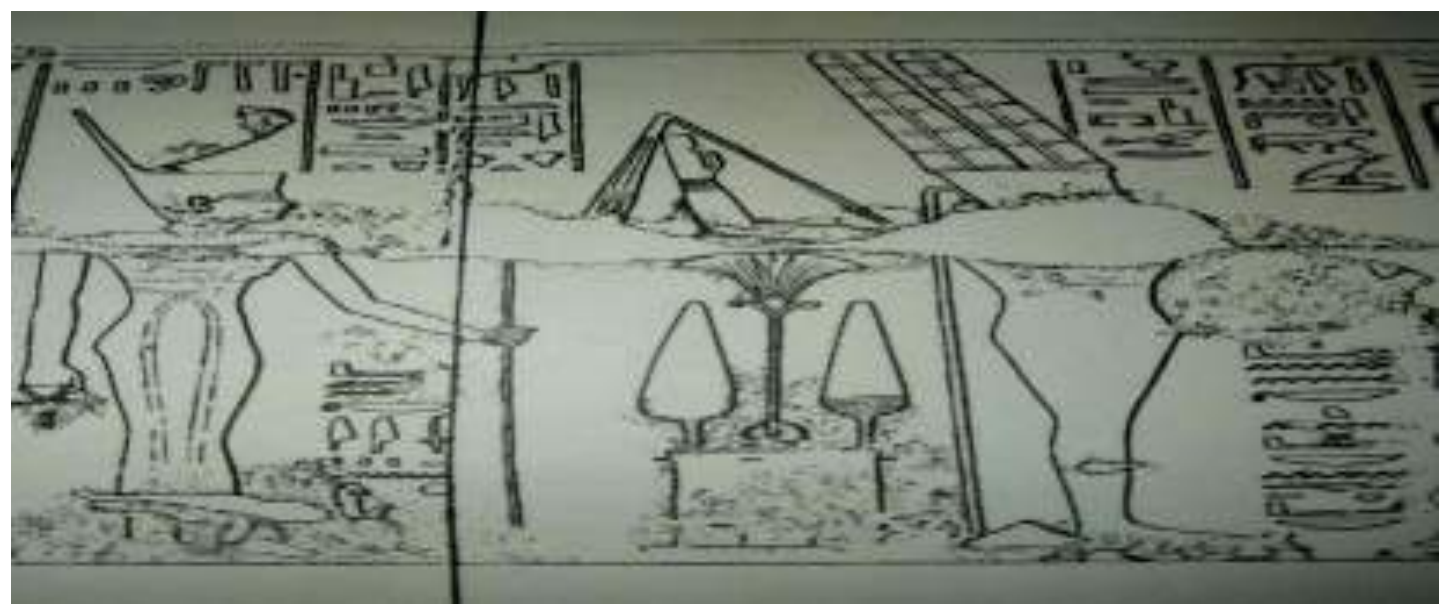

Fig.9- The temple proper, first pylon, north tower, top, interior, passage at foot of upper staircase, east wall. - The Epigraphic Survey, OIP84, Medinet Habu, Vol. 6, Chicago, 1963, pl.435. 
Scenes of Goddess Amaunet in the temple of Medinet Habu

Aya Ahmed El-Mahdy - Khaled El Bassiouny - Mofida EL weshahy

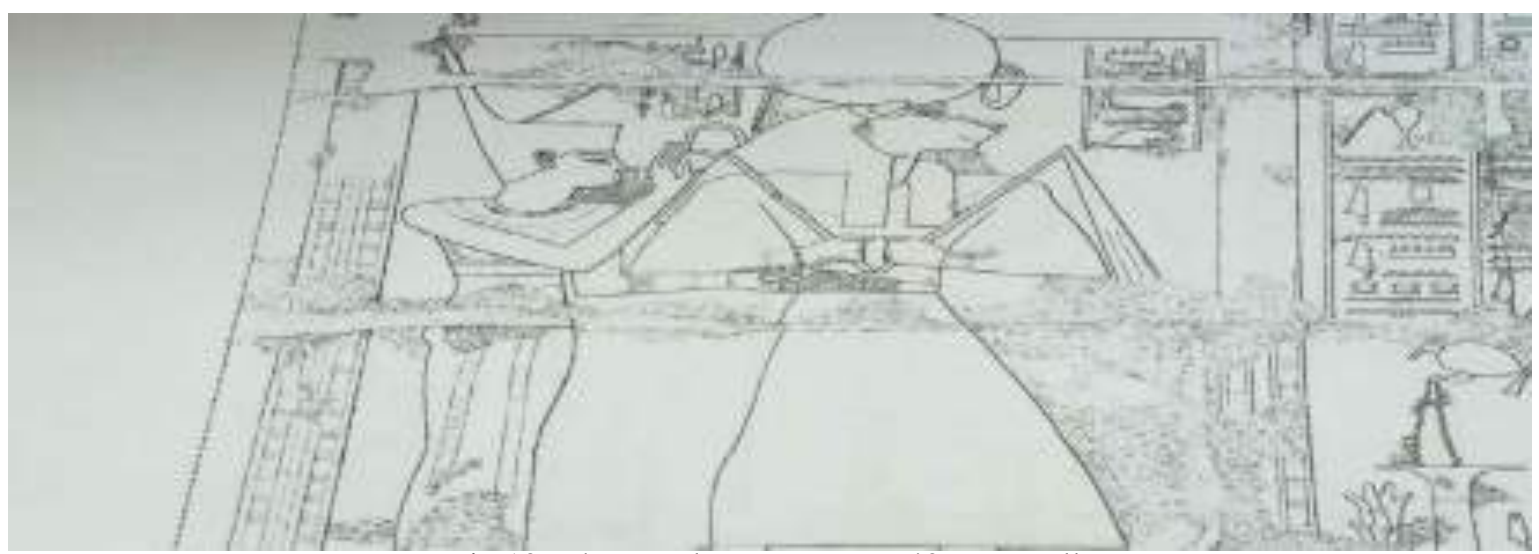

Fig.10- The temple proper, room40, east wall.

- The Epigraphic Survev, OIP93. Medinet Habu. Vol. 7. Chicago, 1964, pl.512.

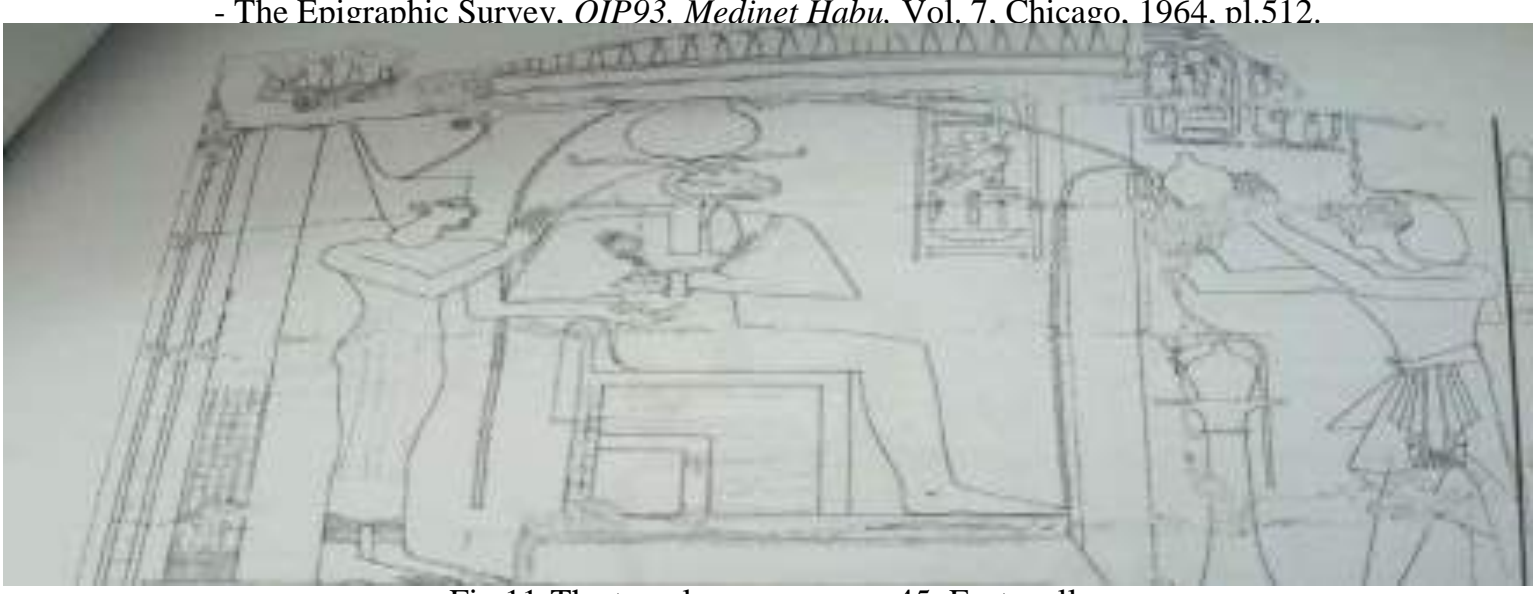

Fig.11-The temple proper, room45, East wall.

- The Epigraphic Survey, OIP93, Medinet Habu, Vol. 7, Chicago, 1964, pl.527.

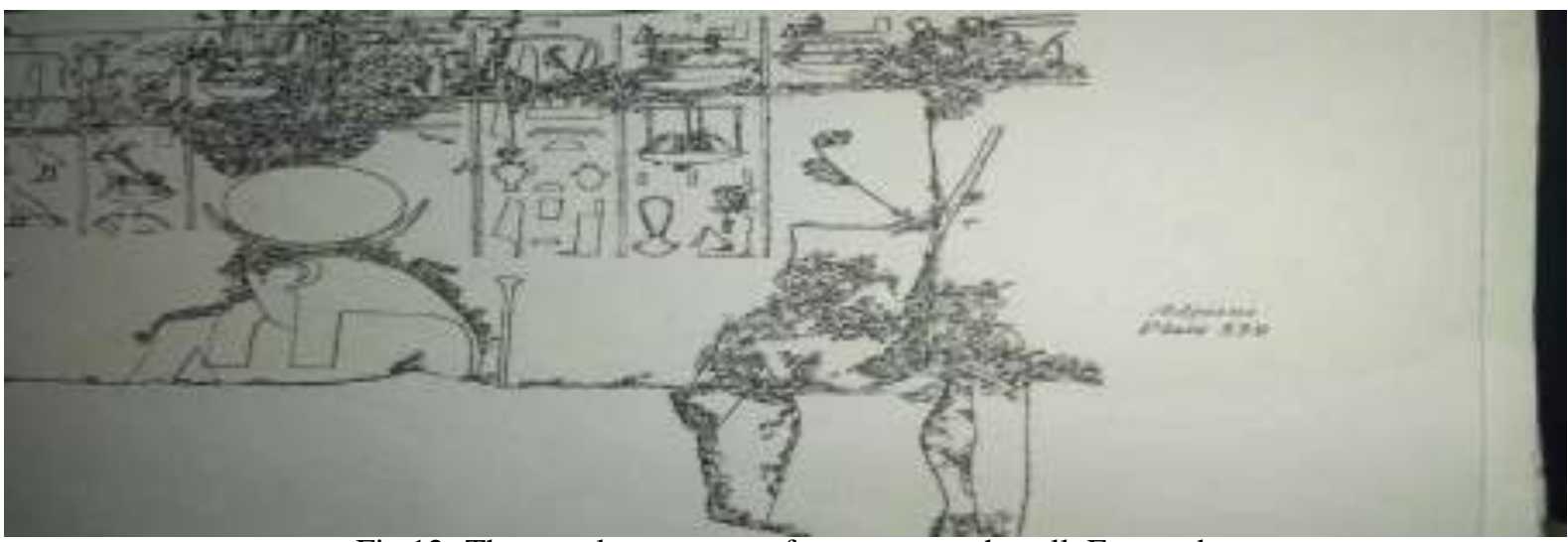

Fig.12- The temple proper, roof terraces, south wall, East end. - The Epigraphic Survev, ibid. pl.558.

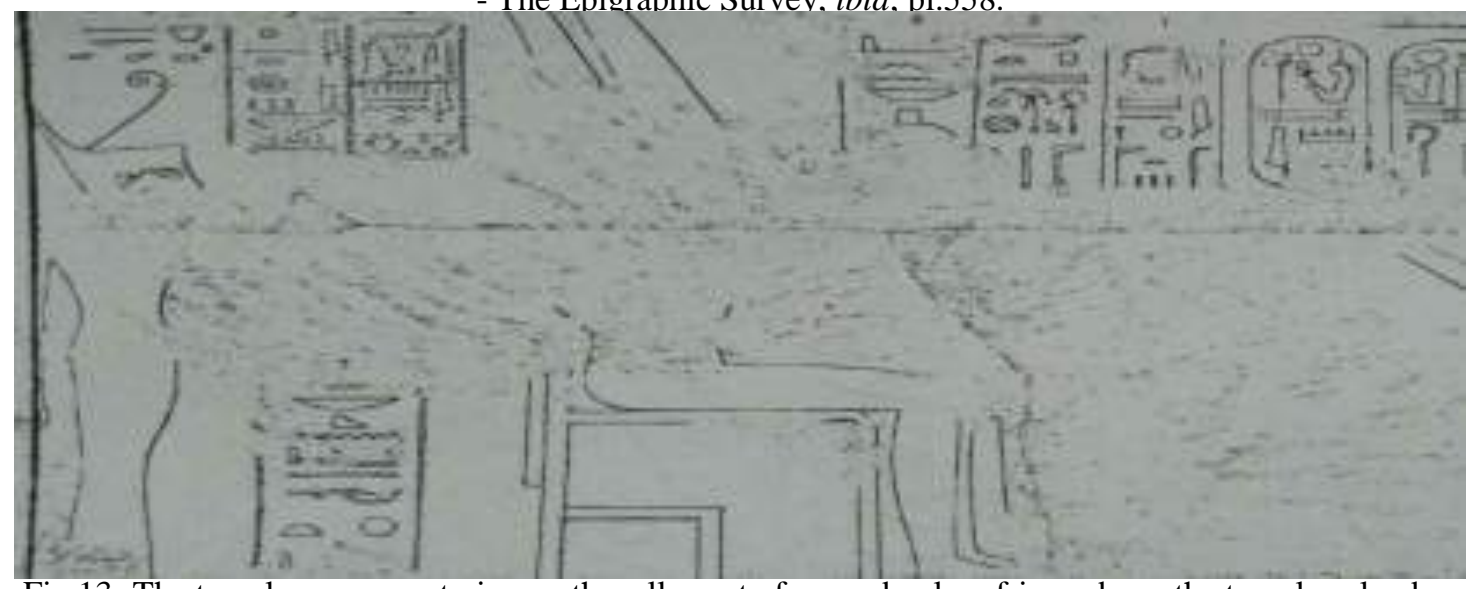

Fig.13- The temple proper, exterior south wall, west of second pylon, frieze above the temple calendar. -Epigraphic Survey, OIP93, Medinet Habu, Vol. 7, Chicago, 1964, pl.574. 


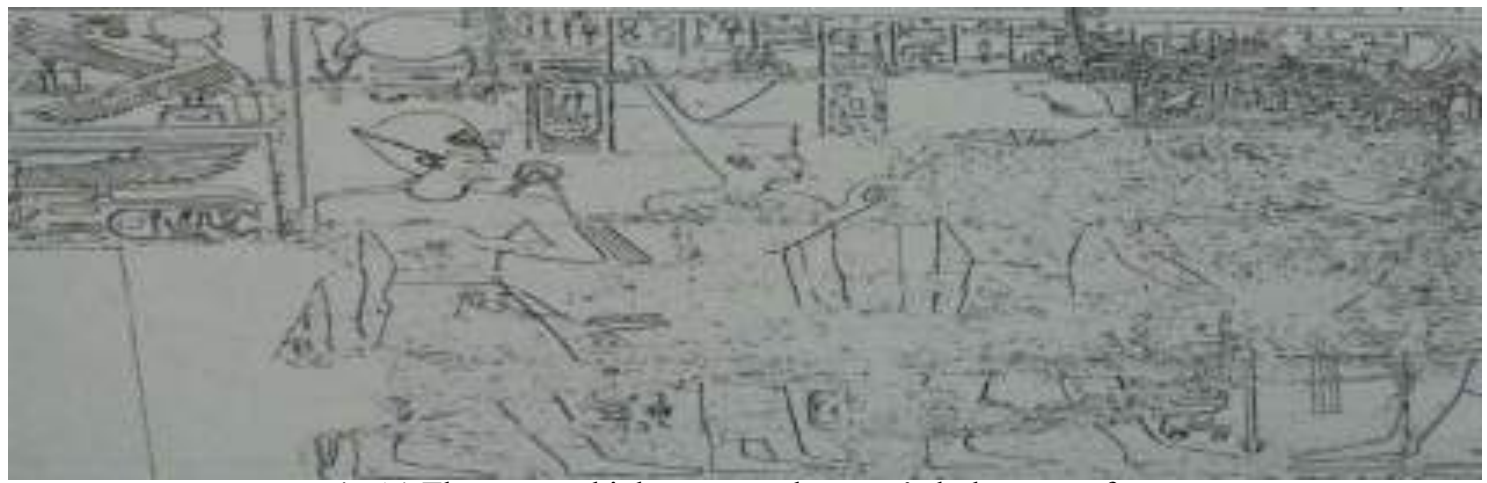

Fig.14-The eastern high gate, north porter's lodge, west face.

- The epigraphic survev, OIP94. Medinet Habu. Vol.8. Chicago, 1970. Pl. 597

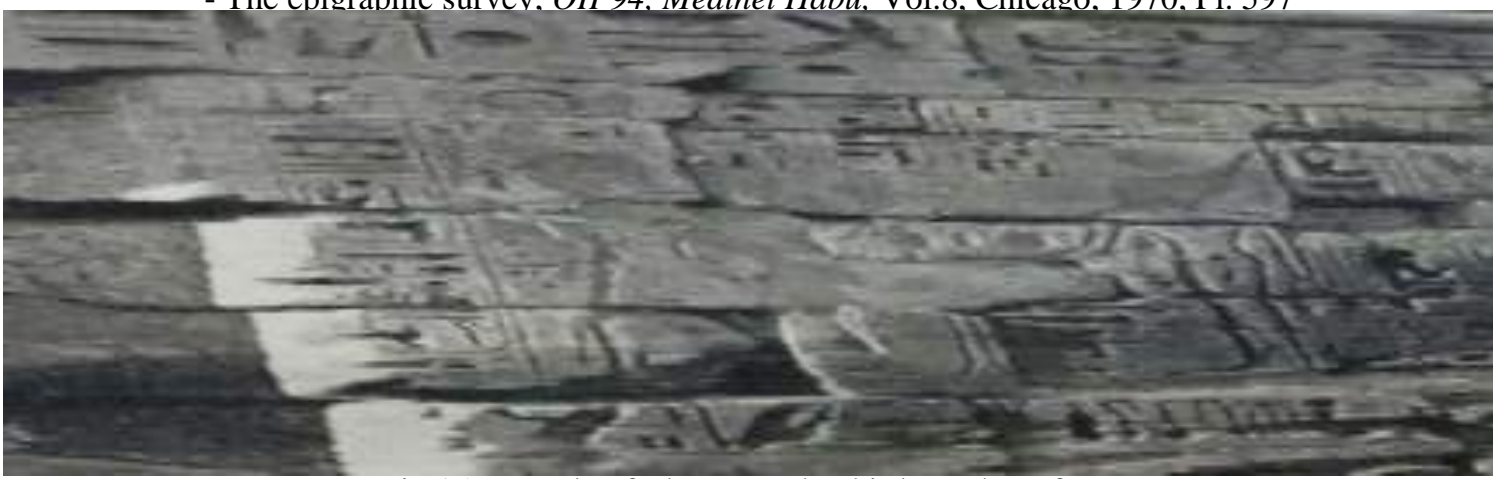

Fig.15- Temple of Thutmose the third, northern face.

References:

- Jéquier, G., L'Architecture ET la Décoration Dans l'ancienne égypte, I, Paris, 1920, Pl.44/3

(1) Nienberg R.St., Medinet Habu, Lexikon der Agyptologie, Band III, Wiesbaden,1980 /1255

(2) Wilkinson, Richard H., The complete temples of Ancient Egypt, Cairo, 2005, P.193.

(3) Stadelmann,R., “ Tempel und Tempelnamen in Theben-Ost und-West”,MDAIK34, 1978,174.

(4) Faulkner R., A Concise Dictionary of middle Egyptian, Oxford, 1991, p.9.

(5) Faulkner R.,Ibid,P.319.

(6)Hölscher,The excavation of Medinet Habu, vol.2,Chicago,1939,P.43

(7) Borchardt, Ludwig, Ägyptische Tempel mit Umgang, Cairo, 1938,P.84

(8) Borchardt, Ludwig, Ibid, P.84.

(9) Sethe, k., Amun und die ucht Urgotter von Hermopolis,Berlin',1929,P.

(10)Faulkner, Raymond O., A concise dictionary of middle Egyptian, Oxford, 1991, P.21.

(11)Lesko, Barbara S.,The Great goddesses Of Egypt, Norman : University of Oklahoma Press, 1999, P.131

(12) Lesko, Barbara S.,ibid, P.265

(13)Lepsius,R., über Die Götter Der Vier Elemente Bei Den Ägyptern,Berlin,1856,P.189.

رندل كلارك، الرن و الأسطورة في مصر القدبية، ترجمة: أحمد صليحة، الهيئة المصرية العامة للكتاب،

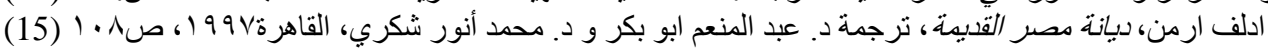

(16) One of the most basic and prominent type of royal headdresses, an old crown attested from the pre. Dynastic period onward, it is most commonly called dSrt "the red one", and nt "independent from the middle kingdom as referring to goddess Neith marked him as ruler of lower Egypt: Emma B. T. Crowns, The Oxford Encyclopedia OfAncient Egypt, 2001, p.323.

(17)Wilkinson,R., The complete gods and goddesses of Ancient Egypt, Cairo, 2003, P.136.

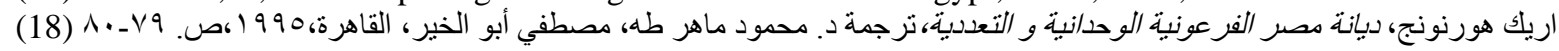

(19)Erman,A.,The Literature of the ancient Egyptians : poems, narratives and manuals of instruction, from the third and second millenia B.C, London,1927, P.368.

(20) Budge,E.A., Gods of the Egyptians or studies in Egyptian Mythology,Vol.1, London,1904,P.465

(21) Hart, George, The Routledge dictionary of Egyptian gods and goddesses, $2^{\text {nd }}$ edition, USA, 2005, P28.

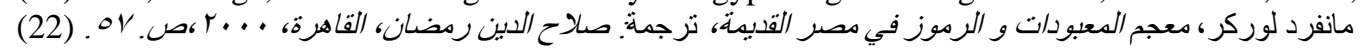

(23)Bonnet,Hans, Reallexikon der Agyptischen Religions Geschichte,Berlin,1952,P.32.

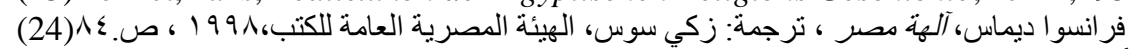

(1) Hart, George, The Routledge dictionary of Egyptian gods and goddesses, $2^{\text {nd }}$ edition, USA, 2005, P28.

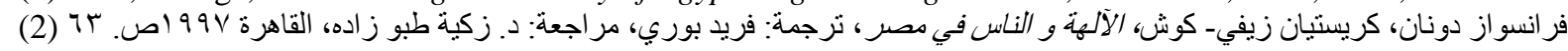

(3) Teeter, Emily, OIP118, Scarabs, scaraboids, seals, and seal impressions from Medinet Habu, Chicago, 2003 , p.19. 
(4) Teeter, Emily, ibid, p.20.

(5) Teeter, Emily, ibid, p.20.

(6) Sign represents papyrus staff, was one of the sacred symbols which refer to prosperity and pleasure: Wilkinson,

R., symbols, in: The Oxford Encyclopedia of Ancient Egypt, vol3, 2001, p.332.

(7) A Hieroglyphic sign refers to life, and it is one of the most famous signs which pharaohs and gods held in

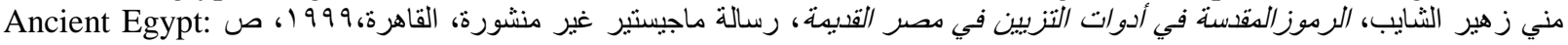
$.17 V_{-} 10 \leqslant$

(8) A Hieroglyphic sign represents a stick with an animal head and the word wAs refers to authority and power: Clark, R., symbols and magic in Egyptian art, London,1994, p.238

(9) Holscher,Uvo, OIP 41,The Excavation of Medinet Habu, Vol.2,Chicago,1939, Pl.38, 39.; Jequier, Justave, L' Architecture III, Les Temples Ptolemaiques et Romains, Paris, 1924, Pl. 10.

(10) Chic. OR. Ins. Photos, 1448.

(11) Champollion, Monuments De L' Egypte et De La Nubie, Notices Descriptives, Paris, 1929, p.316.

(12) Faulkner, R., Concise Dictionary of middle Egyptian, Oxford, 1991, p. 126.

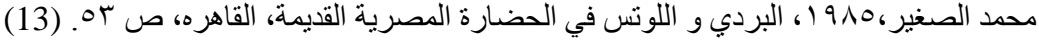

(14) Sethe, k., Amun und die ucht Urgotter von Hermopolis, Berlin,, 1929,P.

(15)Principally called swty (the Two feathers), may have a pair of ostrich or falcon feathers.As a royal crown, this type is attested from the reign of senferu on the fourth dynasty onward: Emma Brunner Traut, in The Ox. E. Of A. E., 2001, Crowns, p323.

(16)Originally an instrument used by goatherds for collecting ladanum and it symbolizes power: عبد الحليم نور (I)

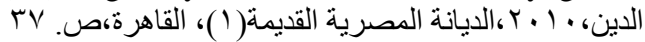

(17)The Epigraphic Survey, OIP83, Medinet Habu, Vol.5, Chicago, 1957, pl. 284(A).

(19) Champollion, op cit, p.329.

(20) The Epigraphic Survey, OIP83, Medinet Habu, Vol.5, Chicago, 1957, pl. 274(A).

(21)Jéquier, G., L’Architecture et la Décoration Dans l'ancienne égypte, II, Paris, 1922, P1.59/2.

(22) The Epigraphic Survey, ibid, pl.324.

(23) Lepsius, Denkmaler Aus Aegypten Und Aethiopien Text III, Leipzig, 1904/ 158.

(24) The Epigraphic Survey, OIP83, Medinet Habu, Vol.5, Chicago, 1957, pl.327.

(25) The Epigraphic Survey, OIP84, Medinet Habu, Vol. 6, Chicago, 1963, pl.366.

(26) LD Text III, 185.

(27)The five day jubilee celebration of the $30^{\text {th }}$ year of a pharaoh's reign :Margret R. bunson, Oxford Encyclopedia of Ancient Egypt,New York,2000,p.163.

(28) 跑 (blue crown): Faulkner, R., op, cit, p.189.

(29)The Epigraphic Survey, OIP84, Medinet Habu, Vol. 6, Chicago, 1963, pl.374.

(30)The Epigraphic Survey, OIP84, Medinet Habu, Vol. 6, Chicago, 1963, pl.435.

(31) The Epigraphic Survey, OIP93, Medinet Habu, Vol. 7, Chicago, 1964, pl.512.

(32) The Epigraphic Survey, OIP93, Medinet Habu, Vol. 7, Chicago, 1964, pl.527.

(33) The Epigraphic Survey, ibid, pl.558.

(34) R., Wilkinson, The complete gods and goddesses of Ancient Egypt, Cairo, 2003, p.113

(35) The Epigraphic Survey, OIP93, Medinet Habu, Vol. 7, Chicago, 1964, pl.574.

(36) The epigraphic survey, OIP94, Medinet Habu, Vol.8, Chicago, 1970, Pl. 597.

(37)Jéquier, G., L'Architecture et la Décoration Dans l'ancienne égypte, I, Paris, 1920, Pl.44/3
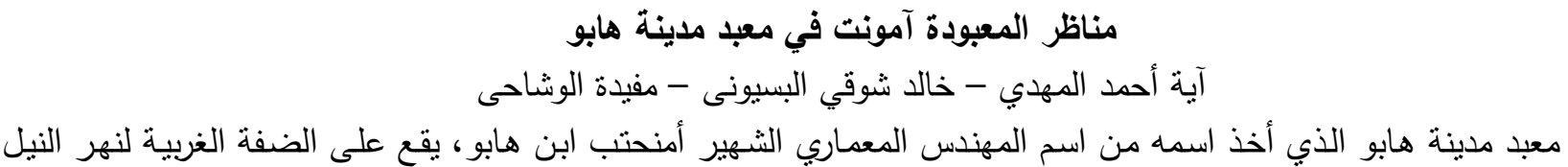

هدفا البحث: - دراسة أهم المناظر والتقديمات الخاصة بالمعبودة آمونت في معبد مدينة هابو؛ - إلقاء الضوء على الدور البارز الذي لعبته الآلهة بالمعبد وعلاقتها بالآلهة الأخرى. الكلمات الدالة : آمونت - هابو - الثامون. 